\title{
UPAYA SUVERVISI AKADEMIK UNTUK MENINGKATKAN KEMAMPUAN GURU MADRASAH DALAM MEMBUAT RPP DI MADRASAH IBTIDAIYAH NEGERI 18 PIDIE
}

\author{
Nurhayati \\ Kementerian Agama Kabupaten Pidie
}

\begin{abstract}
ABSTRAK
Dalam pelaksanaan kurikulum 2013 seorang guru dituntut mampu mengembangkan kurikulum tingkat satuan pendidikan masing-masing dan disesuaikan dengan kebutuhan peserta didik. Kemampuan merencanakan pembelajaran merupakan suatu kompetensi akademik yang perlu dikembangkan secara profesional oleh guru. Masalah penelitian dapat dirumuskan sebagai berikut (1) Aapakah suvervisi akademik yang berkelanjutan mampu meningkatkan kompetensi guru dalam menyusun RPP? (2) Bagaimanakah langkah-langkah pemberian suvervisi akademik yang dapat meningkatkan kompetensi guru dalam menyusun RPP ? Adapun tujuan dilaksanakan penelitian ini adalah sebagai berikut: (1) Membuktikan secara ilmiah suvervisi akademik berkelanjutan dapat meningkatkan keeampuan guru dalam menyusun RPP. (2) Mengetahui langkah-langkah yang tepat dalam meningkatkan kompetensi guru dalam menyusun RPP. Metode yang digunakan dalam penelitian ini ialah penelitian tindakan sekolah (PTS). Penelitian tindakan sekolah ini dilakukan dalam dua siklus dengan mengacu pada karakteristik penelitian tindakan sekolah oleh pengawas binaan. Hasil pengamatan peneliti menunjukkan bahwa ada kenaikan nilai tuntas dari $65 \%$ menjadi $85 \%$. Sedangkan Tidak tuntas ada penurunan dari $77 \%$ menjadi 5\%. Hasil penelitian dapat disimpulkan bahwa kompetensi guru dalam menyusun RPP dengan pendekatan saintifik dan pendekatan BK di Madrasah Ibtidaiyah Negeri 18 Pidie dapat ditingkatkan melalui metode bimbingan teknis dan pelatihan.
\end{abstract}

Kata Kunci: Kompetensi Guru, RPP, Pendekatan BK

\begin{abstract}
In implementing the 2013 curriculum, a teacher is required to be able to develop a curriculum at the level of each educational unit and be adjusted to the needs of students. The ability to plan lessons is an academic competency that teachers need to develop professionally. The research problem can be formulated as follows (1) Can ongoing academic supervision be able to increase teacher competence in preparing lesson plans? (2) What are the steps for providing academic supervision that can improve teacher competence in preparing lesson plans? The objectives of this research are as follows: (1) To prove scientifically sustainable academic supervision can increase the ability of teachers in preparing lesson plans. (2) Knowing the appropriate steps in improving teacher competence in preparing lesson plans. The method used in this research is school action research (PTS). This school action research was conducted in two cycles with reference to the characteristics of school action research by the fostered supervisors. The results of the researchers' observations indicated that there was an increase in the completeness value from $65 \%$ to $85 \%$. Meanwhile, there was a decrease from $77 \%$ to $5 \%$. The results of the study can be concluded that the competence of teachers in preparing lesson plans with a scientific
\end{abstract}


approach and counseling approach in Madrasah Ibtidaiyah Negeri 18 Pidie can be improved through technical guidance and training methods.

Keywords: Teacher Competence, lesson plans, BK approach

\section{PENDAHULUAN}

Pendidikan adalah proses merubah manusia menjadi lebih baik, lebih mahir dan lebih terampil. Untuk mencapai tujuan tersebut tentunya di butuhkan strategi yang disebut dengan strategi pembelajaran. Dalam strategi pembelajaran terkandung tiga hal pokok yakni perencanaan, pelaksanaan dan evaluasi. Perencanaan program berfungsi untuk memberikan arah agar semua program yang sudah di rancang sebelumnya akan sesuai dengan pelaksanaan pembelajaran sehingga menjadi terarah dan efisien.

Pendidikan merupakan sesuatu yang sangat esensial bagi pembentukan karakter sebuah peradaban dan kemajuan yang mengiringinya. Tanpa pendidikan, sebuah bangsa atau masyarakat tidak akan pernah mendapatkan kemajuannya sehingga menjadi bangsa atau masyarakat yang kurang atau bahkan tidak beradab. Karena itu, sebuah peradaban yang memberdayakan akan lahir dari suatu pola pendidikan dalam skala luas yang tepat guna dan efektif bagi konteks dan mampu menjawab segala tantangan zaman. Di samping itu, pendidikan adalah wahana untuk mencetak generasi muda yang sangat penting bagi masa depan Negeri ini. Tanpa ada pendidikan yang baik dan berkualitas, tentu saja negeri ini akan terancam karena anak mudanya di didik secara serampangan dan tidak sesuai dengan nafas kemajuan zaman yang semakin cepat ini. Dan untuk mendapatkan pendidikan yang berkualitas tentu saja segala yang berkompeten di dalamnya harus bekerja keras untuk memberikan yang terbaik dalam memajukan pendidikan.

Pendidikan yang bermutu merupakan harapan dari setiap warga negara termasuk di Indonesia. Pendidikan yang bermutu akan menghasilkan sumber daya yang bermutu pula, diatur dalam Undang-undang RI Nomor
20 Tahun 2003 tentang Sistem Pendidikan Nasional, Bab II Pasal 3, menyatakan bahwa,"Pendidikan nasional berfungsi mengembangkan kemamp uan dan membentuk watak serta peradaban bangsa yang bermartabat dalam rangka mencerdaskan kehidupan bangsa". Hal ini menyiratkan sikap profesionalisme dalam dunia pendidikan menjadi penting, tidak hanya sekadar nilai formalitas tetapi harus fungsional dan menjadi prinsip dasar yang melandasi aksi operasionalnya. Ditinjau dari faktor manajemen, khususnya manajemen pendidikan menurut Sahertian, ada tiga faktor utama yang menyebabkan rendahnya mutu pendidikan, yaitu: (1) instrumental sistem pendidikan, (2) sistem manajemen pendidikan, (3) substansi manajemen pendidikan, antara lain kualitas tenaga pendidik yang kurang profesional, kualitas personil yang kurang memadai yaitu dalam arti penempatan orang yang tepat sesuai dengan kompetensi yang diperlukan untuk kinerja yang efektif dan efisien belum sesuai, dan tingkat kesejahteraan guru yang rendah.

Tenaga guru adalah salah satu tenaga kependidikan yang mempunyai peran sebagai salah satu faktor penentu keberhasilan tujuan pendidikan, karena guru yang langsung bersinggungan dengan peserta didik, untuk memberikan bimbingan yang akan menghasilkan tamatan yang diharapkan. Guru merupakan sumber daya manusia yang menjadi perencana, pelaku dan penentu tercapainya tujuan organisasi. Guru merupakan tulang punggung dalam kegiatan pendidikan terutama yang berkaitan dengan kegiatan proses belajar mengajar. Tanpa adanya peran guru maka proses belajar mengajar akan terganggu bahkan gagal. Oleh karena itu dalam manajemen pendididikan peranan guru dalam upaya keberhasilan pendidikan selalu ditingkatkan, kinerja atau prestasi kerja guru harus selalu ditingkatkan 
mengingat tantangan dunia pendidikan untuk menghasilkan kualitas sumber daya manusia yang mampu bersaing di era global. Simamora menyatakan dalam Moh Uzer Usman bahwa kinerja merupakan suatu persyaratan-persyaratan tertentu yang akhirnya secara langsung dapat tercermin dari output yang dihasilkan baik yang berupa jumlah maupun kualitasnya. Output yang dihasilkan menurut Simamora dapat berupa fisik maupun nonfisik yang menyebutnya berupa karya, yaitu suatu hasil/pekerjaan baik berupa fisik/material maupun nonfisik maupun non material.

Seorang guru dalam mengerjakan tugasnya dengan baik, seringkali ditentukan oleh penilaian terhadap kinerjanya. Penilaian tidak hanya dilakukan untuk membantu mengawasi sumber daya organisasi namun juga untuk mengukur tingkat efisiensi penggunaan sumber daya yang ada dan mengidentifikasi hal-hal yang perlu diperbaiki. Penilaian terhadap kinerja merupakan faktor penting untuk meningkatkan kinerja dan kepuasan kerja guru, bagian-bagian yang menunjukkan kemampuan guru yang kurang dapat diidentifikasi, diketahui sehingga dapat ditentukan strategi dalam meningkatkan kinerjanya. Menurut Soebagio dalam Soetjupto kepemimpinan pendidikan memerlukan perhatian yang utama, karena melalui kepemimpinan yang baik kita harapkan akan lahir tenaga-tenaga berkualitas dalam berbagai bidang sebagai pemikir, pekerja yang pada akhirnya dapat meningkatkan sumber daya manusia yang berkualitas. Dari pendapat tersebut menunjukkan betapa pentingnya kepala sekolah sebagai sosok pimpinan yang diharapkan dapat mewujudkan harapan bangsa. Oleh Karena itu diperlukan seorang kepala sekolah yang mempunyai wawasan kedepan dan kemampuan yang memadai dalam menggerakkan organisasi sekolah. Dalam peranannya sebagai seorang pendidik, kepala sekolah harus mampu menanamkan, memajukan, dan meningkatkan nilai mental, moral, fisik dan artistik kepada para guru atau tenaga fungsional yang lainnya, tenaga administrasi (staf) dan kelompok para siswa atau peserta didik. Dalam fungsinya sebagai penggerak para guru, kepala sekolah harus mampu menggerakkan guru agar kinerjanya menjadi meningkat karena guru merupakan ujung tombak untuk mewujudkan manusia yang berkualitas. Guru akan bekerja secara maksimum apabila didukung oleh beberapa faktor diantaranya adalah kepemimpinan kepala sekolah.

Dengan demikian bagi kepala sekolah dalam memotivasi guru hendaknya menyediakan peralatan, membuat suasana kerja yang menyenangkan, dan memberikan kesempatan promosi/kenaikan pangkat, memberi imbalan yang layak baik dari segi moneter maupun non moneter. Di samping guru sendiri harus mempunyai daya dorong yang berasal dari dalam dirinya untuk berprestasi dalam karirnya sebagai pendidik, pengajar dan pelatih agar tujuan sekolah (tujuan pendidikan) dapat tercapai. Kepala sekolah sebagai pemimpin sekolah mempunyai tugas yang sangat berat dalam rangka meningkatkan kualitas sekolah. Guru sebagai salah satu komponen yang terpenting dalam pendidikan, terutama dalam hal mengatasi berbagai permasalahan yang berkaitan dengan peningkatan mutu pendidikan, dituntut untuk bisa menjadi guru profesional. Profesionalisme guru tidak akan ada atau berjalan mulus tanpa adanya usahausaha yang dilakukan oleh kepala sekolah, sebab salah satu di antara cara guru agar bisa menjadi guru profesional adalah dengan adanya upaya-upaya yang dilakukan oleh kepala sekolah dalam rangka meningkatkan mutu guru.

Dari observasi awal permasalahan yang muncul tentang upaya kepala sekolah dalam meningkatkan profesionalisme guru, masih kurangnya pengawasan (controling) dari kepala sekolah terhadap kinerja guru, masih ada beberapa guru yang memiliki banyak tugas tambahan, sehingga tugas utama menjadi terganggu, masih ada guru yang 
belum menguasai IT, masih ada beberapa guru yang belum memenuhi standar kompetensinya sebagai guru.

Rendahnya kualitas sumber daya manusia khususnya tenaga pendidik/guru merupakan salah satu masalah utama dalam dunia pendidikan, tenaga pendidik/guru yang berkualitas merupakan salah satu komponen yang sangat penting dalam menentukan keberhasilan dalam mencapai sebuah tujuan pendidikan. Tenaga pendidik/guru yang berkualitas harus ada di dalam sebuah lembaga salah satunya adalah sekolah dasar/madrasah ibtidaaiyah, karena sekolah dasar/ madrasah ibtidaaiyah merupakan sebuah sistem pendidikan yang memiliki tujuan meningkatkan mutu pendidikan, oleh karena itu dapat ditempuh dengan beberapa strategi antara lain: peningkatan kesejahteraan bagi pendidik, mengadakan berbagai jenis kegiatan pelatihan untuk peningkatan kualitas pendidik, dan pembinaan yang dilakukan oleh kepala sekolah bagi pendidik. Hal tersebut dilakukan dengan tujuan untuk meningkatkan kualitas pendidik atau guru terutama dalam mengembangkan proses pembelajaran. Guru sebagai ujung tombak proses pendidikan memiliki banyak dimensi peran yang harus diembannya dalam konteks pencapaian tujuan pendidikan. Sebagai ujung tombak, kualitas guru akan menentukan kualitas mutu layanan dan lulusan yang dihasilkan. Sebagaimana dalam Undangundang No. 14 Tahun 2005 tentang Guru dan Dosen (pasal 1) dinyatakan bahwa," guru adalah pendidik profesional dengan tugas utama mendidik, mengajar, membimbing, mengarahkan, melatih, menilai, dan mengevaluasi peserta didik pada 2 jalur pendidikan formal, pada jenjang pendidikan dasar dan pendidikan menengah". Guru yang profesional harus bisa menerapkan cara mengajar yang baik dan dapat berpengaruh terhadap hasil siswa itu sendiri. Hal tersebut tidak jauh dari peran seorang kepala sekolah. Kepala sekolah bertugas melakukan supervisi, mengkoordinir, membimbing, memotivasi, memimpin dan mengoreksi kepada guru untuk dapat mengetahui sejauh mana kompetensi guru tersebut terutama dalam mengajar dan menyampaikan materi kepada siswa.

Kurikulum 2013 untuk SD/MI menggunakan pendekatan pembelajaran tematik integratif dari kelas I sampai dengan kelas VI. Pembelajaran tematik integratif merupakan pendekatan pembelajaran yang mengintegrasikan berbagai kompetensi dan berbagai mata pelajaran ke dalam berbagai tema. Dalam pembelajaran tematik ini para guru memiliki tugas yang cukup berat untuk dapat menerapkan sistem atau metode mengajar terbaru yang lebih dikembangkan lagi sehingga pembinaan dalam hal ini diperlukan terutama terhadap ketidaksiapan guru dengan adanya kurikulum terbaru agar dapat menyesuaikannya. Guru madrasah sendiri dituntut untuk meningkatkan kompetensi menguasai seluruh mata pelajaran yang diajarkan dan menghubungkan setiap mata pelajaran dengan kehidupan sehari-hari sesuai dengan harapan masa depan pendidikan.

Salah satu bagian dari perencanaan pembelajaran yang sangat penting di buat oleh guru sebagai pengarah pembelajaran adalah silabus dan Rencana Pelaksanaan Pembelajaran (RPP). Silabus memberikan arah tentang apa saja yang harus dicapai guna menggapai tujuan pembelajaran dan cara seperti apa yang akan di gunakan. Selain itu silabus juga memuat teknik penilaian seperti apa untuk menguji sejauh mana keberhasilan pembelajaran Rencana Pelaksanaan Pembelajaran (RPP) adalah instrument perencanaan yang lebih spesifik dari silabus. Rencana Pelaksanaan Pembelajaran ini dibuat untuk memandu guru dalam mengajar agar tidak melebar jauh dari tujuan pembelajaran. Dengan melihat pentingnya penyusunan perencanaan pembelajaran ini, guru semestinya tidak mengajar tanpa adanya rencana. Namun ada juga yang tak terlintas dalam pikiran kita 
pada saat ada beberapa faktor yang sering dan dapat luput dari perencanaan pembelajaran yang mestinya dapat diukur oleh kepala sekolah ini, tidak dapat diukur oleh kepala sekolah karena hanya direncanakan dalam pikiran sang guru saja. Akibatnya kepala sekolah sebagai pembuat kebijakan di sekolah tidak dapat mengevaluasi kinerja guru secara akademik. Kinerja yang dapat dilihat oleh kepala sekolah hanyalah kehadiran tatap muka, tanpa mengetahui apakah kemampuan guru dalam mengelola pembelajaran sudah sesuai dengan harapan atau belum, atau sudahkah kompetensi dasar yang harus dikuasai oleh siswa terkuasai dengan benar.

Hasil pengamatan di tahun pelajaran 2009/2010 di Madrasah Ibtidaiyah Negeri 18 Pidie didapatkan data sebagai berikut:

1. Hanya $60 \%$ guru yang menyusun silabus dan RPP.

2. Secara kualitas, silabus dan RPP yang baik baru mencapai angka 30\% dari silabus dan RPP yang dibuat oleh guru.

Untuk mengatasi permasalahan tersebut, peneliti yang berkedudukan sebagai Suvervisi sekolah di atas merencanakan untuk melakukan supervise akademik yang berkelanjutan. Dengan metode tersebut diharapkan setelah kegiatan, guru yangmenyusun silabus dan RPP meningkat menjadi $90 \%$ dan kualitas silabus dan RPP yang baik menjadi $80 \%$.

Dari latar belakang diatas, dapat dirumuskan masalah yang ingin dipecahkanoleh peneliti. Antara lain rendahnya kompetensi guru dalam menyusun rencana pembelajarankhususnya silabus dan rencana pembelajaran, jumlah guru yang menyusun silabus dan RPP sebelum mengajar masih belum maksimal, hanya $60 \%$ kualitas silabus dan RPP yang disusun oleh guru masih belum baik. Hanya 30\% silabus dan RPP yang mutunya baik.

Dari hasil identifikasi masalah yang muncul, peneliti akan membatasi permasalahan yang disinyalir oleh peneliti sebagai akar permasalahan dari semua masalah yang teridentifikasi yaitu rendahnya kompetensi guru dalam menyusun rencana pembelajaran khususnya silabus dan RPP.

Berdasarkan latar belakang dan pembatasan masalah yang telah diuraikan diatas, maka masalah pokok dalam penelitian ini dapat dirumuskan apakah supervisi akademik yang berkelanjutan mampu meningkatkan kompetensi guru dalam menyusun silabus dan RPP?, Bagaimanakah langkah-langkah pemberian supervise akademik yang dapat meningkatkan kompetensi guru dalam menyusun silabus dan RPP?

Penelitian tindakan sekolah ini diharapkan dapat memberi manfaat bagi kepala sekolah dalam memecahkan masalah guru, meningkatkan kompetensi guru dalam melaksanakan tugas- tugasnya sehingga menjadi lebih professional, meningkatkan prestasi siswa dalam pembelajaran, dan pada akhirnya meningkatkan kinerja dan mutu sekolah secara keseluruhan. Disamping itu langkah-langkah yang tepat dalam melaksanakan supervise akademik terutama dalam rangka meningkatkan kompetensi guru dalam menyusun silabus dan RPP dapat menjadi referensi ilmiah yang dapat dipertanggungjawabkan guna penanganan kasus serupa bagi pembaca dan pihak - pihak yang berkepentingan.

\section{KAJIAN PUSTAKA}

Pendidikan adalah usaha sadar yang dengan sengaja di rancangkan untuk mencapai tujuan yang telah ditetapkan. Pendidikan bertujuan untuk meningkatkan kualitas sumber daya manusia. Dalam usaha meningkatkan kualitas sumber daya pendidikan, guru merupakan komponen sumber daya manusia yang harus di bina dan dikembangkan terus-menerus. Potensi sumber daya guru itu perlu terus tumbuh dan berkembang agar dapat melakukan fungsinya secara potensial. Selain itu pengaruh perubahan yang serba cepat menuntut guruguru untuk terus-menerus belajar menyesuaikan diri dengan perkembangan 
ilmu pengetahuan dan teknologi serta mobilitas masyarakat. Masyarakat mempercayai, mengakui dan menyerahkan kepada guru untuk mendidik tunas-tunas muda dan membantu mengembangkan potensinya secara professional yang mempunyai cita-cita tinggi. Guru yang profesional adalah mereka yang memiliki kemampuan professional dengan berbagai kapasitasnya sebagai pendidik. Studi yang dilakukan oleh Ace Suryani menunjukkan bahwa Guru yang bermutu dapat diukur dengan lima indikator, yaitu (1) kemampuan profesional (professional capacity), sebagaimana terukur dari ijazah, jenjang pendidikan, jabatan dan golongan, serta pelatihan. (2) upaya profesional (professional efforts), sebagaimana terukurdari kegiatan mengajar, pengabdian dan penelitian. (3) waktu yang dicurahkan untuk kegiatan profesional (teacher's time), sebagaimana terukurdari masa jabatan, pengalaman mengajar serta lainnya. (4) kesesuaian antara keahlian dan pekerjaannya (link and match) sebagaimana yang telah di lakukan sebelumnya bahwa terukur dari mata pelajaran yang diampu, apakah telah sesuai dengan spesialisasinya atau tidak, serta (5) tingkat kesejahteraan (prosperiousity) sebagaimana terukurdari upah, honor atau penghasilan rutinnya. Tingkat kesejahteraan yang rendah bisa mendorong seorang pendidik untuk melakukan kerja sambilan, dan bilamanakerja sambilan ini sukses, bisa jadi profesi mengajarnya berubah menjadi sambilan.

\section{Kompetensi Guru}

Majid menjelaskan kompetensi yang dimiliki oleh setiap guru akan menunjukkan kualitas guru dalam mengajar. Kompetensi tersebut akan terwujud dalam bentuk penguasaan pengetahuan dan profesional dalam menjalankan fungsinya sebagai guru. Di yakini Robotham, kompetensi yang diperlukan oleh seseorang tersebut dapat diperoleh baik melalui pendidikan formal maupun pengalaman. Syah mengemukakan pengertian dasar kompetensi adalah kemampuan atau kecakapan.

Depdiknas merumuskan definisi kompetensi sebagai pengetahuan, keterampilan, dan nilai-nilai dasar yang direfleksikan dalam kebiasaan berfikir dan bertindak. Menurut Syah, "kompetensi" adalah kemampuan, kecakapan, keadaan berwenang, atau memenuhi beberapa faktor serta beberapa syarat menurut ketentuan hukum. Selanjutnya masih menurut Syah, di kemukakan bahwa kompetensi guru adalah kemampuan seorang guru dalam melaksanakan kewajiban-kewajibannya secara bertanggung jawab dan layak. Berdasarkan uraian di atas kompetensi guru sangat tepat serta dapat di definisikan bahwa sebagai penguasaan terhadap pengetahuan, keterampilan, nilai dan sikap yang di refleksikan dalam kebiasaan berpikir dan bertindak dalam menjalankan profesisebagai guru.

2. Tupoksi Kepala Sekolah

Dalam implementasi MBS, kepala sekolah merupakan " the key person" keberhasilan peningkatan kualitas pendidikan di sekolah. Ia adalah orang yang diberi tanggung jawab untuk mengelola dan memberdayakan berbagai potensi masyarakat serta orang tua untuk mewujudkan visi, misi dan tujuan sekolah. Oleh karena itu dalam implementasi MBS kepala sekolah harus memiliki visi, misi, dan wawasan yang luas tentang sekolah yang efektif serta kemampuan profesional dalam mewujudkannya melalui perencanaan, kepemimpinan, manajerial, dan supervisi pendidikan. Ia juga dituntut untuk menjalin kerjasama yang harmonis dengan berbagai pihak yang terkait dengan program pendidikan di sekolah. Singkatnya, dalam implementasi MBS kepala sekolah harus mampu berperan sebagai Educator, Manajer, Administrator, Supervisor, Leader, Innovator dan Motivator. 
Supervisi adalah serangkaian usaha pemberian bantuan kepada guru dalam bentuk layanan professional yang diberikan oleh supervisor ( Pengawas sekolah, kepala sekolah, dan pembina lainnya) guna meningkatkan mutu proses dan hasil belajar mengajar yang dilakukan oleh guru. Karena supervisi atau pembinaan guru tersebut lebih menekankan pada pembinaan guru, maka tersebut pula "Pembinaan profesional guru" yakni pembinaan yang lebih di arahkan pada upaya memperbaiki dan meningkatkan kemampuan profesional guru. Secara umum kegiatan supervise dapat di bedakan dalam dua macam, yaitu: supervisi umum dan supervise akademik. Tujuan supervise akademik adalah Membantu guru mengembangkan kompetensinya, Mengembangkan kurikulum, Mengembangkan kelompok kerja guru dan membimbing penelitian tindakan kelas.

3. Kompetensi Pedagogik

Pedagogik berasal dari kata paedagogia yang berarti pergaulan dengan anak, Pedagogi yang merupakan praktik pendidikan anak dan kemudian muncullah istilah "Pedagogik yang berarti ilmu mendidik anak." Dengan demikian, pedagogik merupakan teori mendidik yang mempersoalkan apa dan bagaimana mendidik. Oleh sebab itu pedagogik dipandang sebagai suatu proses atau aktivitas yang bertujuan agar tingkah laku manusia mengalami perubahan. Kompetensi pedagogik adalah kemampuan guru dalam mengelola pembelajaran peserta didik, yang meliputi merancang pembelajaran, melaksanakan pembelajaran, merancang dan melaksanakan evaluasi, mengembangkan siswa untuk mengaktualisasikan berbagai potensinya peserta didik, serta memahami diri secara mendalam.

Wibowo dan Hamrin mendefinisikan kompetensi pedagogik adalah pemahaman guru terhadap anak didik, perencanaan, pelaksanaan pembelajaran, evaluasi hasil belajar, dan pengembangan anak didik untuk mengaktualisasikan sebagai potensi yang dimilikinya. Berdasarkan beberapa definisi di atas, maka dapat disimpulkan bahwa kompetensi pedagogik adalah kemampuan yang harus dimiliki oleh seorang guru dalam memahami karakter peserta didik dan kemampuan dalam melaksanakan proses pembelajaran, mulai dari perencanaan, pelaksanaan dan evaluasi, dengan tujuan agar peserta didik mampu mengembangkan dan mengaktualisasikan berbagai potensi yang ada.

Dari penjelasan di atas dapat dipahami bahwa standar kompetensi guru khususnya kompetensi pedagogik yang harus dimiliki adalah kemampuan untuk memahami karakteristik peserta didik, kemempuan untuk memahami teori belajar dan prinsipprinsipnya, memahami kurikulum, melaksanakan pembelajaran dengan benar, memanfaatkan teknologi informasi dan komunikasi, mampu memfasilitasi potensi peserta didik, berkomunikasi secara efektif, empatik, dan santun dengan peserta didik, mampu melaksanakan dan memanfaatkan hasil penilaian dan evaluasi, serta melakukan tindakan reflektif untuk peningkatan kualitas pembelajaran.

\section{METODE PENELITIAN}

Penelitian ini merupakan penelitian deskriptif kuantitatif. Menurut Suharsimi Arikunto pada umumnya penelitian deskriptif merupakan penelitian nonhipotesis sehingga dalam langkah-langkahnya penelitian ini tidak perlu merumuskan hipotesis.Statistik deskriptif digunakan untuk mengorganisasi data, menyajikan, dan menganalisis data. Cara untuk menggambarkan data adalah dengan melalui teknik statistik seperti membuat tabel, distribusi frekuensi, dan diagram atau grafik. Penelitian ini tidak bertujuan untuk menguji hipotesis tertentu, tetapi hanya menggambarkan apa adanya tentang suatu variabel, gejala, atau keadaan, dengan demikian penelitian ini bertujuan menggambarkan apa adanya tentang 
supervisi akademik kepala sekolah dalam pembinaan terhadap penyusunan RPP. Tempat penelitian adalah tempat yang digunakan dalam melakukan penelitian untuk memperoleh data yang diinginkan. Penelitian ini dilaksanakan di Madrasah Ibtidaiyah Negeri 18 Pidie. Peneliti mempunyai alasan bahwa lokasi tersebut merupakan satu-satunya lembaga Madrasah Ibtidaiyah Negeri 18 Pidie, dimana kerap menjadi contoh bagi sekolah-sekolah lain.

Pada tahap ini penulis menjelaskan bagaimana tahap perencanaan pelitian tindakan supervisi. Pada tahap ini kegiatan yang direncanakan peneliti adalah sebagai berikut:

1. Mengidentifikasi permasalaham guru

2. Menyusun perencanaan pembuatan tema PTS

3. Penjelasan tentang tata cara dan langkahlangkah proposal pembuatan PTS

4. Melakukan penelitiaan

5. Evaluasi

Penelitian dilakukan selama 2 bulan, mulai dari Agustus sampai September tahun 2019.

Adapun pembagian waktu penelitian dapat diperinci seperti pada tabel 1 :

\begin{tabular}{|c|c|c|c|c|c|c|c|c|c|}
\hline \multirow{3}{*}{ Kegiatan } & \multicolumn{8}{|c|}{ Waktu } & \multirow{3}{*}{ Ket } \\
\hline & \multicolumn{4}{|c|}{ Agustus } & \multicolumn{4}{|c|}{ September } & \\
\hline & 1 & 2 & 3 & 4 & 1 & 2 & 3 & 4 & \\
\hline $\begin{array}{l}\text { Pengajuan } \\
\text { Proposal }\end{array}$ & & & & & & & & & \\
\hline $\begin{array}{l}\text { Penyusunan } \\
\text { Rancangan }\end{array}$ & & & & & & & & & \\
\hline $\begin{array}{l}\text { Pelaksanaan } \\
\text { Siklus I }\end{array}$ & & & & & & & & & \\
\hline $\begin{array}{l}\text { Analisis Hasil } \\
\text { Siklus I }\end{array}$ & & & & & & & & & \\
\hline $\begin{array}{l}\text { Pelaksanaan } \\
\text { Siklus II }\end{array}$ & & & & & & & & & \\
\hline $\begin{array}{l}\text { Analisis Hasil } \\
\text { Siklus II }\end{array}$ & & & & & & & & & \\
\hline $\begin{array}{l}\text { Penulisan Hasil } \\
\text { penelitian }\end{array}$ & & & & & & & & & \\
\hline
\end{tabular}

Dalam penelitian ini penulis mendeskripsikan dalam bentuk 2 siklus, masing-masing siklus terdiri dari perencanaan, pelaksanaan, observasi dan refleksi. Populasi adalah keseluruhan subjek penelitian. Dijelaskan pula oleh Suharsimi Arikunto, bila populasi kurang dari 100 satuan, sebaiknya penelitian dilakukan terhadap keseluruhan populasi. Dalam penelitian ini, populasinya adalah beberapa guru di Madrasah Ibtidaiyah Negeri 18 Pidie. Data Teknik pengumpulan data yang digunakan dalam peneltian ini adalah teknik angket tertutup dan wawancara tidak terstruktur. Alasan penelitian ini menggunakan teknik angket agar dalam proses pengambilan data bisa lebih efektif dan efisien. Alasan lain yaitu keterbatasan tenaga, biaya, dan waktu yang dimiliki peneliti sehingga memilih metode angket dalam pengambilan data. Angket yang digunakan dalam penelitian ini adalah angket tertutup langsung, yang akan di isi oleh kepala sekolah untuk mengetahui kinerjanya dalam melakukan supervisi akademik kepada guru di sekolahnya. Angket tertutup dalam bentuk kuesioner dimana dalam setiap butir pertanyaan akan diisi sendiri oleh kepala sekolah sesuai keadaan dari pertanyaan tersebut. Data yang diperlukan dalam penelitian ini berupa pernyataan atau jawaban yang diperoleh dari guru Madrasah Ibtidaiyah Negeri 18 Pidie. Langkah-langkah mengumpulkan data yaitu dengan menyerahkan angket kepada responden yaitu kepala sekolah, dan langsung diminta untuk mengisi. Setelah itu dikumpulkan lalu hasilnya langsung di jabarkan dalam tabel frekuensi.

\section{HASIL PENELITIAN}

Subjek pada penelitian ini adalah guru Madrasah Ibtidaiyah Negeri 18 Pidie. Subjek yang diteliti sebanyak 10 orang. Objek yang diteliti dalam penelitian ini adalah supervisi akademik oleh pengawas Madrasah Ibtidaiyah Negeri 18 Pidie dengan fokus penelitian intensitas pembinaan penyusunan 
RPP. Dalam penyusunan RPP, guru biasanya bekerja sama dengan rekan guru dalam satu gugus. Mekanisme yang dilakukan adalah dengan membagi tugas antar guru dalam kelas yang sama untuk menyusun RPP tiap pertemuan dan dikumpulkan saat awal semester untuk kemudian di perbanyak sesuai jumlah guru yang membutuhkan. Kemampuan guru dalam menggunakan multimedia sangat kurang walaupun ada beberapa guru yang sudah mampu menguasai tehnik-teknik yang dasar dalam menggunakan multimedia ketika proses belajar mengajar. Dari hasil suvervisi penulis sebagai pengawas Madrasah Ibtidaiyah Negeri 18 Pidie hanya $38 \%$ guru yang mampu menggunakan multimedia untuk proses mengajar sedangkan $62 \%$ masih mengajar dengan metode ceramah dan mencatat materi mata pelajaran. Rendahnya pemahaman guru dalam menggunakan multimedia disebabkan kurangnya bimbingan serta pelatihan kusus dan juga pendampingan langsung dari orang yang profesional dalam bidang informasi dan tekhnologi. Berikut ini adalah deskripsi Siklus I.

\section{Perencanaan (Planning)}

a. Mengundang guru untuk hadir sebagai nara sumber penelitian.

b. Penelitiana ini di lakukan dalam 2 bulan dan telah di rinccikan dalam tabel diatas.

c. Meminta guru membawakan hasil evaluasi belajar dalam mata pelajaran disekolahnya serta RPP, materi dan rencana akademik.

d. Pada pertemuan pertama penulis akan menggali pengetahuan guru tentang bagaimana menyusun RPP yang efektif.

e. Penulis meminta untuk mengutarakan kemudahan dan kesulitan dalam menyusun RPP.

f. Pada pertemuan selanjutnya penulis memberikan arahan dan bimbingan dalam menyussun RPP yang efektif.

g. Pada pertemuan terakhir penulis meminta guru untuk menyimpulkan metode dalam menyusun RPP yang efektif dan tepat sasaran.

2. Pelaksanaan

a. Bimbingan Teknis pada siklus II dilakukan selama satu minggu pada bulan agustus 2019. Kegiatan ini di mulai pada pukul 14.00 sampai dengan 16.00 yang bertempat di ruang pertemuan guru.

b. Pengawas meminta pihak sekolah untuk mempersiapkan segala kebutuhan bimbingan teknis.

c. Pengawas melakukan bimbingan teknis terhadap 10 guru pada Madarasah Ibtidaiyah Negeri 18 Pidie dengan materi yang sudah disusun sebelumnya.

d. Pengawas melakukan evaluasi serta penilaian dari hasil bimbingan teknis tersebut.

3. Pengamatan

Selama melakukan penelitian penulis juga melakukan pengamatan di sekolah yang berkaitan dengan perkembangan sistem belajar mengajar, aktivitas guru dan pengamatan tentang perkembangan serta peningkatan kemampuan guru dalam menyusun RPP. Tabel dibawah ini hasil pengamatan peneliti pada siklus I pada saat jam mengajar dan saat pertemuan rutinitas di Madrasah Ibtidaiyah Negeri 18 Pidie .

\begin{tabular}{|c|l|c|}
\hline No & \multicolumn{1}{|c|}{ Nama } & $\begin{array}{c}\text { Skor } \\
\text { Penilaaian }\end{array}$ \\
\hline 1 & Aidil Sani, S. Pd. I & 3 \\
\hline 2 & Lisnawati & 3 \\
\hline 3 & Risnawati, S. Pd. I & 3 \\
\hline 4 & Sri Devi Wulandari, S. Pd & 3 \\
\hline 5 & Aisyah, S. Pd. I & 3 \\
\hline 6 & Sally Hanidar, S. Pd. I & 3 \\
\hline 7 & M.Idris, S. Pd. I & 3 \\
\hline 8 & Rusnaani, S. Pd. I & 3 \\
\hline 9 & Lina Fadhilah, S. Pd. I & 3 \\
\hline 10 & Maryani, S. Pd. I & 3 \\
\hline \multicolumn{2}{|l|}{ Persentase Rata-rata } & Cukup \\
\hline \multicolumn{2}{|l|}{ Katagori }
\end{tabular}

Refleksi

Keberhasilan dalam meningkatkan kemampuan guru menyusun RPP daalam 
proses belajar mengajar akan dapat kita simpulkan dalam proses dan hasil. Proses penelitian ini sekaligus menjadi bimbingan teknis menyususn RPP dalam mengajar akan berhasil apabila pada pengamatan dan observasi aktivitas guru sebanyak $85 \%$ mendapat katagori baik. Pada aktivitas pengawas sebagai pemberi bimbingan pun memperoleh penilaian baik dan amat baik. Dan apabila nantinya guru memperoleh kurang dari $85 \%$ dari indikator keberhasilan yang ditetapkan maka tindakan bimbingan belum berhasil dan harus dilanjutkan dengan tindakan siklus II.

Berdasarkan hasil pengamatan di atas dapat kita simpulkaan bahwa tahap awal atau siklus I kemampuan guru dalam menyusun RPP masih sangat jauh dari harapan. Bahkan setelah dilakukan beberapa kali uji dalam menyusun RPP hanya $38 \%$ guru yang menguasai cara menyussun dengan efekttif.

Tabel Hasil Tes Kemampuan Guru Pada Siklus I

\begin{tabular}{|c|c|c|c|c|}
\hline No & Skala & Jumlah & Persent & Keterangan \\
\hline 1 & $85-100$ & 1 & $10 \%$ & Amat Baik \\
\hline 2 & $75-86$ & 1 & $10 \%$ & Baik \\
\hline 3 & $65-76$ & 2 & $40 \%$ & Cukup \\
\hline 4 & $55-64$ & 4 & $20 \%$ & Kurang \\
\hline 5 & $\leq 54$ & 2 & $20 \%$ & Sangat Kurang \\
\hline
\end{tabular}

Pada dasarnya siklus II memiliki prosedur yang sama dengan siklus I, hanya saja perlu dilakukan tindakan-tindakan serta perbaikan pada poin-poin yang dilihat ada kelemahan serta mempertimbangkan hal-hal yang sudah berjalan denngan baik. Tidak menutup kemungkinan juga dilakukan modifikasi terhadap hal-hal sudah baik supaya tindakan yang diberikan tidak merasa jenuh.

Setelah berdiskusi panjang lebar dengan kepala sekolah dan pihak yang terkait mka dapat di tarik kesimpulan bahwa perlu dilakukan tindak lanjut untuk meningkatkan kompetensi guru dalam menyusun RPP.
Tabel hasil tes kemampuaan pada Siklus II

\begin{tabular}{|c|c|c|c|c|}
\hline No & $\begin{array}{c}\text { Skala } \\
\text { Nilai }\end{array}$ & $\begin{array}{c}\text { Jumlah } \\
\text { Guru }\end{array}$ & Persentase & Keterangan \\
\hline 1 & $85-100$ & 6 & $60 \%$ & Amat Baik \\
\hline 2 & $75-86$ & 3 & $30 \%$ & Baik \\
\hline 3 & $65-76$ & 1 & $10 \%$ & Cukup \\
\hline 4 & $55-64$ & - & - & Kurang \\
\hline 5 & $\leq 54$ & & - & $\begin{array}{c}\text { Sangat } \\
\text { Kurang }\end{array}$ \\
\hline
\end{tabular}

Hasil uji kemampuan dalam menggunakan multimedia pada siklus II sebanyak 10 orang guru sudah sesuai dengan mendapatkan nilai yang amat baik sehingga bimbingan teknis dan bisa dikatakan sebagai sebuah perkembangan kemampuan guru yang signifikan. Penelitian ini bertujuan untuk mendeskripsikan pelaksanaan supervisi akademik di Madrasah Ibtidaiyah Negeri 18 Pidie. Pelaksanaan supervisi diihat dari intensitas pembinaan kepala sekolah dalam penyusunan RPP guru kelas 4, 5, dan 6 yang mencakup tujuan, pengorganisasian materi ajar, kesesuaian materi ajar, pemilihan sumber dan media, skenario pembelajaran, penilaian hasil belajar. Intensitas pembinaan yang dilakukan oleh kepala sekolah di Madrasah Ibtidaiyah Negeri 18 Pidie sangat jarang. Jawaban tiap responden menyatakan bahwa rata- rata kepala sekolah melakukan pembinaan sebanyak 2 kali dalam satu semester. Padahal dalam program yang telah disepakati bersama, kepala sekolah memiliki target melakukan pembinaan sebanyak 6 kali dalam 1 semester kepada masing-masing guru. Secara geografis, Madrasah Ibtidaiyah Negeri 18 Pidie berada dalam wilayah pantai dan pegunungan, yaitu pantai. Beberapa kepala sekolah berasal dari luar kecamatan yang kemungkinan menyebabkan rendahnya intensitas kepala sekolah dalam melakukan pembinaan kepada guru, dikarenakan tugas kepala sekolah yang sudah sangat banyak 
ditambah jarak tempuh menuju tempat kerja sangat jauh. Berdasarkan hasil penelitian, diketahui bahwa mayoritas pembinaan yang dilakukan oleh kepala sekolah adalah sebanyak 2 kali dalam satu semester. Hal ini dikarenakan kepala sekolah memiliki tanggung jawab yang sangat banyak sehingga tidak bisa memenuhi rencana pelaksanaan pembinaan yang mana akan dilakukan setiap bulan satu kali pada tiap-tiap guru.

Dengan demikian dapat disimpulkan bahwa semakin tinggi kelasnya maka kepala sekolah akan semakin jarang melakukan pembinaan, dikarenakan biasanya guru kelas 6 merupakan guru terbaik yang ditugaskan oleh kepala sekolah agar maksimal dalam membimbing siswasiswanya menghadapi Ujian Sekolah dan Ujian Nasional yang menjadi tolok ukur peringkat sekolah. Dengan melihat hasil ujian nasional, masyarakat dapat menilai sekolahan mana yang nilai nya tinggi sehingga mempengaruhi animo masyarakat yang ingin menyekolahkan anaknya ke sekolahan yang berkualitas baik. Dengan demikian guru yang mengajar kelas 6 akan fokus dan mempersiapkan RPP dengan sungguh-sungguh sehingga kepala sekolah percaya terhadap kemampuan guru tersebut. Rata rata pembinaan yang dilakukan kepala sekolah adalah 2 kali dalam satu semester. Hal ini dikarenakan pernyataan beberapa kepala sekolah berdasarkan instruksi pengawas kabupaten yang menyatakan bahwa pembinaan terhadap guru dilakukan minimal 2 kali saja sudah cukup.

\section{PENUTUP}

Berdasarkan hasil penelitian dan pembahasan seperti yang telah disampaikan pada uraian diatas, maka dalam penelitian ini dapat disimpulkan sebagai berikut. Pelaksanaan supervisi akademik untuk meningkatkan kemampuan guru dalam menyususn RPP oleh kepala Sekolah Madrasah Ibtidaiyah Negeri 18 Pidie, sebagian besar dilakukan sebanyak 2 kali dalam satu semester. Hal ini dikarenakan pengawas kabupaten pernah menyatakan bahwa minimal supervisi akademik dilakukan pada awal dan akhir semester. Hambatan yang ditemui oleh kepala sekolah antara lain: keterbatasan waktu untuk melaksanakan supervisi akademik karena banyaknya tanggung jawab yang harus di selesaikan. Adanya senioritas dalam lingkup sekolahan sehingga bagi kepala sekolah swasta yang usia muda dan belum PNS merasa sungkan dengan guru PNS yang sudah senior. Upaya yang dilakukan untuk mengatasi adalah kepala sekolah membuat jadwal dan sering melakukan supervisi kelas setiap harinya sesuai waktu yang dimiliki dan memperhatikan iklim belajar mengajar.

Berdasarkan hasil penelitian, pembahasan dan kesimpulan yang telah dilakukan, maka peneliti mengemukakan saran sebaiknya Kepala Sekolah selalu berusaha menjalankan tugas dan tanggung jawabnya dalam kegiatan supervisi akademik. Serta dalam pembinaan penyusunan RPP, sebaiknya tidak hanya dilaksanakan satu atau dua kali saja dalam satu semester, karena RPP merupakan panduan guru dalam mengajar sehingga semakin sering kepala sekolah membina guru dalam penyusunannya diharapkan dapat meningkatkan kualitas pembelajaran. Semakin sering kepala sekolah melakukan pembinaan diharapkan guru tidak lagi menyusun RPP secara asal-asalan. Kepala sekolah disarankan merubah kebiasaan memberi tanda tangan persetujuan RPP di awal semester, sebaiknya tanda tangan dilakukan setiap minggu sehingga guru membuat RPP baru setiap akan mengajarkan materi, dengan demikian kecenderungan "copy paste" bisa dikurangi. Kepala sekolah juga bisa menyusun jadwal terstruktur untuk melakukan pembinaan tentang RPP dan memberikannya kepada guru, sehingga ketika kepala sekolah lupa atau terlalu sibuk dengan kegiatan lainnya, guru dapat mengingatkan dan tetap menyerahkan susunan RPP nya. 


\section{DAFTAR PUSTAKA}

Anwar, Moch. Idochi. 2004. Administrasi Pendidikan dan Manajemen Biaya Pendidikan. Bandung: Alfabeta.

Depdiknas. 1997. Petunjuk Pengelolaan Adminstrasi Sekolah Dasar. Jakarta: Depdiknas.

Depdiknas. 2001. Manajemen Peningkatan Mutu Berbasis Sekolah. Jakarta: Depdiknas. Depdiknas. 2010. Supervisi Akademik; Materi Pelatihan PenguatanKemampuan Kepala Sekolah; Jakarta: Depdiknas.

Harahap, Baharuddin. 1983. Supervisi Pendidikan yang Dilaksanakan oleh Guru, Kepala

Sekolah, Penilik dan Pengawas Sekolah. Jakarta

Muhaimin (2004). Paradigma Pendidikan Islam. Bandung: PT Remaja Rosdakarya. Mulyasa, E., 2003. Kurikulum Berbasis Kompetensi: Konsep, Karakteristik, dan Implementasi. Bandung: PT Remaja Rosdakarya

Sahertian, Piet A. 2000. Konsep-Konsep dan Teknik Supervisi Pendidikan Dalam Rangka Pengembangan Sumber Daya Manusia. Jakarta: Rineka Cipta.
Sapari, Achmad. 2002. Pemahaman Guru Terhadap Inovasi Pendidikan. Artikel. Jakarta

Kompas (16 Agustus 2002).Supandi. 1996. Administrasi dan Supervisi Pendidikan. Jakarta: Departemen Agama Universitas Terbuka.

Suprihatin, MD. 1989. Administrasi Pendidikan, Fungsi dan Tanggung Jawab Kepala

Sekolah sebagai Administrator dan Supervisor Sekolah. Semarang: IKIP Semarang Press.

Surya, Muhammad. 2003. Psikologi Pembelajaran dan Pengajaran. Bandung: Yayasan Bhakti Winaya

Suryasubrata.1997. Proses Belajar Mengajar di Sekolah. Jakarta: Rineka Cipta

Usman, Moh. Uzer. 1994. Menjadi Guru Profesional. Bandung: PT Remaja Rosdakarya. Wahidin; 13 Faktor untuk menjadi Kepala Sekolah Yang Efektif , 2008

Wardani, IGK. 1996. Alat Penilaian Kemampuan Guru (APKG). Jakarta: Dirjen Dikti

Damai Jaya Majid, Abdul. 2005. Perencanaan Pembelajaran: Mengembangkan Standar Kompetensi Guru. Bandung: PT Remaja Rosdakarya. 